\author{
Aleksandra Višekruna, M.A., Research Associate \\ Institute of Comparative Law \\ Terazije 41, Belgrade, Serbia \\ avisekruna@gmail.com
}

\title{
PROTECTION OF RIGHTS OF COMPANIES BEFORE THE EUROPEAN COURT OF HUMAN RIGHTS ${ }^{1}$
}

\begin{abstract}
The relation between companies and human rights is usually observed through the concept of corporate social responsibility, i.e. companies being human rights violators. However, this subject can be observed from a different angle that is gaining greater significance nowadays the possibility for companies to protect their rights before the European court of human rights (ECtHR). The aim of this paper is to determine how the scope of human rights protection has evolved and expanded. From the basic notion of human right belonging to a human being to the idea that this term can be expanded to capture 'human rights of companies' (Emberland). Indisputably company's right to property can be protected before the ECtHR, as it is officially recognised under Protocol No. 1 of the European convention on human rights. However, the case law has gradually started to expand the scope of the Convention to other rights that were not explicitly granted to companies - first by recognising procedural rights to companies, and later by recognising rights such as right to respect for private and family life (article 8), freedom of expression (article 10) and right to just satisfaction (article 41) (so-called 'hard cases'). This expandedpersonal scope of the Convention is raising many controversies. The major concern is that granting right to companies would diminish the rights of natural persons, as companies would utilise their newfound position to avoid honouring rights of natural persons. The question is where this case law dynamics will lead us to - shall we soon be raising the issue of company's right to life. Also, there is the issue whether shareholders have right to sue in case of violation of rights of their companies.
\end{abstract}

Keywords: human rights, companies, European convention on human rights, European court of human rights.

\section{INTRODUCTORY REMARKS}

Companies are invaluable members of legal order and economy of one country. As such they operate in the web of legal norms on the national and international level. The concept of the legal personality of companies evolved from the idea that company is a mere legal fiction to the idea that it is a legal subject in full right,

This paper is a result of project Srpsko i evropskopravo - uporedivanje i usaglašavanje (No. 179031) financed by the Ministry of education, science and technological development of the Republic of Serbia. 
separated from its human substratum. ${ }^{2}$ It was generally accepted they can have obligations and rights under the national law but the status of the company in the international legal framework remains ambiguous. The answer depends on which legal instrument we observe. Analysis has shown that European convention on human rights (ECHR) affords the widest scope of rights to companies. ${ }^{3}$

Companies' relations to human rights have mostly been linked to corporate social responsibility and grave breaches of fundamental rights of individuals. ${ }^{4}$ Thus, the idea of corporate human rights will, at first sight, appear contradictory - an oxymoron. ${ }^{5}$

\section{HUMAN RIGHTS OF COMPANIES - PRO ET CONTRA}

The essential question is certainly should companies enjoy human rights and if so, under what conditions and to which extent. Theory has given arguments both in favour and against the extensive interpretation of human rights protection. Some don't deny that certain rights can apply to corporations but consider that unjustified. ${ }^{6}$

Reasons in favour of extending the scope of rights can be summed up as follows: affording rights to companies provides protection not only for the entity but also protects interests of natural persons and acts as a safeguard for the rule of law and democratic society. ${ }^{7}$ Granting human rights to companies wouldn't deprive human beings of their rights but would make companies more aware of the need for human rights protection. ${ }^{8}$ Case Yukos v. Russia ${ }^{9}$ is seen as a perfect example why companies should enjoy protection - possibility to appear before ECtHR offers a

2 Isiksel T., The Rights of Man and the Rights of the Man-Made: Corporations and Human Rights. URL< https://ssrn.com/abstract=2546401>. Accessed 13 April 2015, pp. 44 etc.

3 Van Kempen, P. H., The Recognition of Legal Persons in International Human Rights Instruments: Protection Against and Through Criminal Justice?, Pieth, M.; Ivory, R. (eds.), Corporate Criminal Liability, Netherlands, 2011, pp. 358-364.

4 Oliver, P., Companies and Their Fundamental Rights: A Comparative Perspective, International and Comparative Law Quarterly, Vol. 64, Issue 3, 2015, p. 663.

5 Grear, A., Redirecting human rights: Facing the challenge of corporate legal humanity, Hampshire, 2010, p. 1.

6 Scolnicov, A., Lifelike and lifeless in law: Do corporations have human rights?, University of Cambridge Faculty of Law Research Paper No. 13, 2013, URL <https://ssrn.com/abstract=2268537>. Accessed 30 September 2016, p. 6.

$7 \quad$ Van Kempen, op.cit. note 3, pp. 371, 386-387.

8 Dhooge, L. J., Human Rights for Transnational Corporations, J. Transnat'l L. \&Pol'y, Vol. 16, 2006, pp. 205-206.

9 OAO Neftyanaya Kompaniya Yukos v. Russia (Just satisfaction) (2014) App. no. 14902/04. 
corporation whose rights were violated by its own state an independent international venue for judicial review. ${ }^{10}$

Some theorists consider that corporations must enjoy certain fundamental rights that are essential to their purpose and functioning but those rights are not necessarily as extensive as those of natural persons or non-profit entities. ${ }^{11}$ Legal persons should be offered protection under each human right that can reasonably be applied to them. ${ }^{12}$ Some authors base their considerations on the fact that companies should enjoy protection only in a measure that is necessary to protect rights of natural persons within them. ${ }^{13}$ Others claim the opposite -corporation has legal personality separated from its members and isn't reducible to, nor interchangeable with its human substratum for the purposes of human rights attribution. ${ }^{14}$

Criticism encompasses conceptual incompatibilities (human rights can only be extended to human beings), practical difficulties (overabundance of applications) and assertions that if companies refuse to accept human rights 'obligations, they should not be able to benefit from their protection. ${ }^{15}$ The firstnegative argument is related to the human vulnerability as the underlying value of human rights law. ${ }^{16}$ Furthermore, companies can use this new development to promote and protect their interests, regardless of the consequences for natural persons ${ }^{17}$ Granting rights to companies often leaves humans vulnerable and corporations protected. ${ }^{18}$ Companies can undermine government efforts to improve of human rights protection, ${ }^{19}$ making it harder for individuals to hold corporations accountable. ${ }^{20}$ Extension of scope is also criticised on the grounds that corporations tend to

10 Van den Muijsenbergh WH.; Rezai S., Corporations and the European Convention on Human Rights, Pac. McGeorge Global Bus. \& Dev. LJ, Vol. 25, 2012, pp. 62, 68.

11 Oliver, op. cit.note 4,p. 695.

12 Van Kempen, op.cit. note 3, p. 387.

$13 \mathrm{Ku}$, J. G., The Limits of Corporate Rights Under International Law, Chi. J. Int'l L., Vol. 12, 2011, p. 732; Scolnicov, op. cit. note 6, p. 17.

14 Grear, A., Challenging corporate 'humanity': Legal disembodiment, embodiment and human rights, Human Rights Law Review, Vol. 7, Issue 3, 2007, p. 517. Harding C.; Kohl U., Human rights in the market place: the exploitation of rights protection by economic actors, Routledge, 2016, p. 36. Scolnicov, op. cit. note 6, p. 7.

15 Van den Muijsenbergh; Rezai, op.cit. note 10, p. 52.

16 Grear, op. cit. note 14, pp. 520-521. Isiksel, pp. 52, 60. Scolnicov, op. cit. note 6, pp. 15-16.

17 Lafont, C., Should We Take the "Human" Out of Human Rights? Human Dignity in a Corporate World, URL <https://ssrn.com/abstract=2768881>. Accessed 8 October 2016, p. 19; Isiksel,op.cit. note 2, pp. $40,59$.

18 Scolnicov, op. cit. note 6, p. 9.

19 Lafont, op.cit. note 17, p. 20. Isiksel,op.cit. note 2, p. 13. Harding; Kohl, op.cit. note 14, p. 46.

20 Grear, op. cit. note 5, p. 17; Grear, op. cit. note 14, p. 514. 
be in a much more balanced position towards public authorities. ${ }^{21}$ This is especially true for the multinational corporations that can use their economic power to avoid responsibility. ${ }^{22}$ Having that in mind, granting them human rights would be paradoxical. ${ }^{23}$ They should be treated more like a State within the human rights framework - to have obligations but no rights. ${ }^{24}$ Some authors base their criticism on the historical interpretation. Namely, during Convention drafting process companies were gradually left out and don't appear as applicants in the final version of the ECHR. ${ }^{25}$

\section{SCOPE OF THE RIGHTS GRANTED TO COMPANIES}

Despite the initial dilemma whether to grant human rights to companies, steady rise of these cases before ECtHR, shows the number of human rights that the ECtHR has deemed applicable to corporations has grown. ${ }^{26}$ However, thesis not a result of apre-planned strategy to grant protection to corporations but of analysis of specific problems in given cases. ${ }^{27}$ Only remains the question of the scope of rights attributed to companies. ${ }^{28}$ We can single out several of these types of rights under ECHR:

- rights explicitly granted to companies (the right to property);

- rights granted to "everyone", where the ECtHR interpreted that the scope of the norm includes companies as well (freedom of speech, right to privacy and procedural rights);

- "derivative" rights realised through individuals that constitute the company (freedom of association and protection from discrimination) $;{ }^{29}$

${ }^{21} \quad$ Sanchez-Graells, A., Marcos, F., 'Human Rights' Protection for Corporate Antitrust Defendants: Are We Not Going Overboard?, University of Leicester School of Law Research Paper No. 14-04, URL<https:// ssrn.com/abstract=2389715>. Accessed 13 January 2017, p. 10.

22 Van Kempen, op.cit. note 3, p. 388.

23 Harding, Kohl, op.cit. note 14, p. 49.

24 Ibid., p. 50.

25 Scolnicov, op. cit. note 6, p. 5; Harding; Kohl, p. 32. Oposite Van den Muijsenbergh; Rezai, op.cit. note 10, p. 48.

26 Lafont, p. 15. This phenomenon is named "the snowball effect". Emberland, M. Protection Against Unwarranted Searches and Seizures of Corporate Premises under Article 8 of the European Convention on Human Rights: The Colas Est SA v. France Approach, Mich. J. Int'l L., Vol. 25, 2003 , p. 93.

27 Sanchez-Graells; Marcos,op.cit.note 21, p. 3.

28 Oliver, op. cit. note 4, p. 662.

29 Scolnicov, op. cit. note 6, p. 11. 
- rights inextricably linked to human personality and incompatible with artificial nature of the company ${ }^{30}$ - the right to life, ${ }^{31}$ rights against torture and ill-treatment, prohibition of slavery, right to liberty and security and a right to marry. However, boundaries are being constantly pushed and the initial scope stretched beyond recognition. ${ }^{32}$

\subsection{Right to property}

The right to property is the only right explicitly granted to legal persons under ECHR. Having that in mind, we would only like to point to two potentially moot issues. First is the question of protection of shareholders under the ECHR. Shareholding and the rights that stem from it enjoy protection. However, the issue is whether shareholders have a standing before the Court when company's property rights have been violated. ${ }^{33}$ The other is related to intellectual property rights that have only recently emerged as a contentious issue and that can have major implications for the future jurisprudence. They raise the issue of ECtHR's role in shaping innovation policy in Europe and striking appropriate balance between interests of corporations and humans. ${ }^{34}$

\subsection{Procedural rights}

ECHR grants protection during government investigations of law violations and, afterwards, against government decisions imposing sanctions or liability. ${ }^{35}$ Set of procedural rights includes article 6 (fair trial), article 7 (no punishment without law), article 13 (right to an effective remedy) and article 4 of the Seventh Protocol (right not to be tried or punished twice).

It is generally accepted that there is no reason companies should be treated less favourably regarding these rights than individuals since otherwise they cannot enforce their rights. ${ }^{36}$ However, it is still unclear whether granting procedural guarantees to a legal person is a matter of legal policy or obligation derived from the

\footnotetext{
$30 \quad$ Van den Muijsenbergh; Rezai, op.cit. note10, p. 50.

31 Some fear that case law would eventually result in granting companies right to life which would interfere with necessary state regulation of corporations (especially registration and liquidation). Van den Muijsenbergh; Rezai, op.cit. note 10, pp. 51, 60; Dhooge, op.cit.note 8, p. 239.

32 Harding; Kohl, op.cit.note 14, p. 28.

33 For detailed discussion see Part 4 of the paper.

34 Helfer, L. R. The New Innovation Frontier-Intellectual Property and the European Court of Human Rights, Harv. Int'l LJ, Vol. 49, 2008, p. 6.

35 Sanchez-Graells; Marcos,op.cit.note 21, p. 8.

36 Oliver, op. cit.note 4, p. 678.
} 
fundamental legal acts. ${ }^{37}$ As Article 6 indicates, its guarantees apply both to the civil and criminal procedure. ${ }^{38}$ Criminal procedure gives reasons for greater concern, especially in the scope of human rights of the accused legal person and the issue of representation of a legal person in criminal proceedings. ${ }^{39}$

The self-incrimination privilege raises the most controversies. The right aims primarily to protect the defendant against having to give evidence that has no existence outside of his/her will. ${ }^{40}$ The content of the principle is determined by criminal legal norms and the case law of ECtHR and it encompasses verbal communication and non-verbal forms of acting. The former relates to defendant's right to remain silent, and the latter to the right of the defendant to refuse to give the incriminating evidence. ${ }^{41}$

Some deny this right to companies because it was primarily established to protect individuals from torture and attack on their physical integrity by the state organs. ${ }^{42}$ Companies are far more equipped to resist state's coercion mechanisms. ${ }^{43}$ Furthermore, granting company this privilege would undermine state's efforts to conduct an effective monitoring of company's activity, as it would discourage whistle-blowers and encourage concealment of information. ${ }^{44}$ Others grant companies this right providing the pressure is put on those that represent the company (management or employees). ${ }^{45}$ Whether legal persons can invoke this privilege depends on its legal foundations. If the root of the privilege is in human dignity and protection of personality, there is no legitimate reason for its extension to legal persons. On the contrary, if the privilege is seen to derive from the rule of law, then it relates to all of the defendants in criminal proceedings, including legal persons. ${ }^{46}$

37 Đurđević Z., Pravna osoba kao okrivljenik: temeljna prava i predstavljanje, Hrvatski ljetopis za kazneno pravo i praksu, Vol. 12, Issue 2, 2005, p.740.

38 We cannot disregard competition law investigations that are considered to fall under the criminal law procedures, but it is stated that company shouldn't enjoy full benefits of the fair trial because it would diminish the effectiveness of competition law enforcement. Sanchez-Graells; Marcos, op.cit. note 21, p. 19.

39 Đurđević,op.cit. note 37, p. 740.

$40 \quad$ Van Kempen, op.cit. note 3, p. 375.

$41 \quad$ Đurđević,op.cit. note 37,p. 757.

42 Scolnicov, op. cit. note 6, p. 22. Oliver, op. cit.note 4, 685. Isiksel, op.cit.note 2,pp. 51-52.

43 Dhooge, op.cit. note 8, p. 241.

44 Ibid.

45 Van Kempen, op.cit. note 3, p. 376.

46 Đurđević,op.cit. note 37, p. 757. 


\section{3. "Hard cases"}

In practice several articles of the ECHR gave rise to the disagreement between theorists regarding whether they can apply to companies at all, or on equal footing with natural persons.

\subsubsection{Right to respect for private and family life (article 8)}

Privacy in its broadest sense is the right to personal autonomy, to self-fulfilment and to develop one's personality. In the narrow sense, this notion covers "freedom from prying" by the State or third parties. Privacy in the economic sphere is considered to fall under the latter concept. ${ }^{47}$

Article 8 grants four rights - respect for family life, respect for private life, respect of home and correspondence. The protection under this article envelops companies, though not in respect of all the interests covered and less extensively and intensively than with respect to individuals. ${ }^{48}$ Clearly, due to their nature companies cannot have family or private life. ${ }^{49}$ However, the ECtHR case law suggests that they can have their home and correspondence protected under this article. The first relevant case on this matter was Société Colas Est v France $^{50}$ where ECtHR found that company's right to home was violated by the French authorities, who entered the premises without the consent of the management and without a judicial authorization (though under law at that time the warrant was not necessary). Even though the word "home" is primarily associated with natural persons, the Court extended its meaning to business premises, because the French text of the ECHR uses the word "domicile" that has a broader connotation than the one in the English version ("home"). ${ }^{51}$ The interpretation of the Article poses two questions. What is the rationale behind widening the scope? Is there any difference inthe scope of the protection of companies and individuals?

47 Oliver, P., The protection of privacy in the economic sphere before the European Court of Justice, Common Market Law Review, Vol. 46, 2009, p. 1443.

48 Van Kempen, op.cit. note 3, p. 377.

49 Scolnicov, op. cit. note 6, p. 14. To claim otherwise „would seem to stretch language beyond all reasonable limits". Oliver, op. cit. note 47, p. 1449.

50 Société Colas Est and Others v. France(2004) 39 EHRR 17.

51 The ECHR consists of two authentic versions written in English and French that are equally binding. In this case, confronted with versions of a treaty that are equally authentic but not exactly the same, the Court opted for interpreting the Convention text in effective rather than formalistic manner. Emberland, op. cit. note 25 , p. 88 . 
Interpreting the concept of "home" in this case shifted from formalistic-linguistic inquiries - whether a company can have a "home" - to a teleological inquiry - what is the purpose of Article 8's protection of the "home".$^{52}$ The protection of the rule of law is seen as an underlying value of the Convention. ${ }^{53}$ Having that in mind, Article 8 should be interpreted not only as a protection of the individual, but of private activity in general (both personal and commercial) from arbitrary exercise of governmental power. ${ }^{54}$ However, some authors acknowledge that corporations have a legitimate interest in commercial secrecy, but deny them human right of privacy. ${ }^{55}$

Caselaw shows that companies enjoy more limited protection under Article 8 than individuals or legal entities not involved in commercial matters, especially concerning the right to respect for one's home. ${ }^{56}$ It appears that the ECtHR has adopted a system under which corporate premises (offices, branches and other business premises) enjoy a lower degree of protection than the residences of individual persons ${ }^{57}$ (two-tiered scheme of protection). ${ }^{58}$ Namely, Article 8(2) establishes conditions under which rights of beneficiaries can be restricted governmental actions must be prescribed by the law, conform to one of the enumerated interests and must be necessary. ${ }^{59}$

\subsubsection{Freedom of speech}

Freedom of expression is recognised as an essential prerequisite of the democratic political process and the development of every human being. ${ }^{60}$ In the era of enhanced commercialisation, the perception that this freedom does not apply to the economic sphere has been challenged. ${ }^{61}$ Discourse about freedom of expression of

\footnotetext{
$52 \quad$ Ibid., p. 89.

53 Van den Muijsenbergh; Rezai,op.cit. note 10,p. 56.

54 Dhooge, op.cit. note 8, p. 235; Emberland, op. cit. note 25, pp. 81, 90-91. Scolnicov, op. cit. note 6, p. 13 .

55 Scolnicov, op. cit. note 6, p. 12.

56 Van Kempen, op.cit. note 3, p. 378.

57 Emberland, op. cit. note 25, p. 100.

58 Ibid., p. 80.

59 In the case Vinci Construction e.a. v France (App. no. 63629/10 et 60567/10), ECtHR concluded that the actions of the authorities conformed to the first two conditions, but that conducted inspections and seizures were disproportionate to the aim pursued and thus violated Article 8 of the ECHR.

60 Macovei, M., Freedom of expression - A guide to the implementation of Article 10 of the European Convention on Human Rights, 2004, URL < https://rm.coe.int/CoERMPublicCommonSearchServices/ DisplayDCTMContent?documentId=090000168007ff48 >. Accessed 1 February 2017, p. 7.

${ }_{61}$ Randall, M. H. Commercial Speech Under the European Convention on Human Rights: Subordinate or Equal?, Human Rights Law Review, Vol. 6, Issue 1, 2006, p. 54.
} 
companies mostly refers to the media enterprises. As the primary transmitters of information in modern democratic societies, media may have a dual capacity - either as violators of freedom of expression or as entities exposed to the infringement of freedom of expression. ${ }^{62}$ ECtHR's decisions show that the Article 10 protection encompasses not only the content of expressions but also the means by which they are communicated. ${ }^{63}$ The most controversial issue regarding this phenomenon and companies is related to the nature of speech that is protected. Namely, the question is whether the pure commercial activity (i.e. an activity exclusively conducted for aims of marketing a product and for purposes of pecuniary gain), may qualify as an "expression" worthy of protection under ECHR, ${ }^{64}$ as opposed to other forms of speech, and particularly political speech. ${ }^{65}$ Political speech enjoys stronger protection due to its part in the preservation of pluralism of opinions in the society, ${ }^{66}$ its role as a check on governmental power and the fact that is more susceptible to governmental censorship. ${ }^{67}$

ECHR provides restrictions on freedom of expression under Article 10 (2), which grants the state right to derogate the rights under circumstances which are essentially the same as in Article 8(2). Under these provisions, authorities are granted wider discretion when it comes to assessing the commercial expression. The Court has basically, depending on the content of information and ideas which are to be conveyed, established a hierarchy of values protected under Article 10 and provides different levels of protection for different categories of expression (political, commercial, artistic, academic, etc.). ${ }^{68}$ Under this two-tiered system commercial speech is scrutinised according to a more lenient standard of review than other forms of protected speech $^{69}$ and can be imposed greater restrictions than political speech. ${ }^{70}$ The double standard is justified on the grounds that the state has a legitimate need for control over economic activity and that economic activity is

62 Aleksovski Đorđević S. Article 10 of the European convention in light of the jurisprudence of the European Court of Human Rights. FACTA UNIVERSITATIS-Law and Politics, Vol. 14, Issue 1, 2016, p. 56.

63 Van den Muijsenbergh; Rezai,op.cit. note 10, p. 57.

64 Ibid.

65 Political speech can be described as comments provided by the media and public figures on issues of public concern. Aleksovski Đorđević,op.cit. note 62,p. 57.

66 Ibid.

${ }_{67}$ Harding, Kohl, op.cit.note 14, p. 207. Randall,op.cit. note 61, pp. 80, 84.

68 Aleksovski Đorđević, op.cit. note 62, p. 57.

${ }_{69}$ Emberland, op. cit. note 25, p. 104; Randall, p. 63. So far, ECtHR has explored boundaries of the commercial speech in the area of advertisement, unfair competition law and broadcasting. Randall, p. 59.

70 Harding; Kohl, op.cit.note 14, p. 201. 
remote from the essential purpose of certain ECHR provisions. ${ }^{71} \mathrm{We}$ can suppose that the reason can be the fear that unrestricted free speech of companies would be abused - companies would drown dissenting voices using the advantage of their economic strength. ${ }^{72}$

This divide is criticised on the two grounds - lack of objective reasons to differentiate between categories of speech and efforts to make the difference are often futile because of the practical difficulties that arise. ${ }^{73}$ Special problem poses situation when it isn't (easy) to determine whether the speech is in the realm of the commercial or political sphere. If the expression is not aimed at promoting the speaker's products or services but is intended to advocate a certain cause, it is not considered to be commercial regardless of the fact it was communicated through an advertisement. ${ }^{74}$ It is suggested to treat all categories of speech the same and to balance all the interests involved in an ad hoc fashion. ${ }^{75}$

Granting freedom of speech inevitably leads to cases when the use of this right can damage someone's reputation. This is particularly reflected in the struggle between the need for company's accountability for the sake of consumer protection and company's interest in preserving its reputation as one of its most valuable assets. On the one hand, speech critical of corporations is a key prerequisite for consumer safety. ${ }^{76}$ Large corporations appear as powerful public actors, impacting upon people's lives, and as such should be open to the same kind of criticism as governmental bodies. ${ }^{77}$ On the other hand, the company has a legitimate interest in preserving its reputation, which represents a valuable property interest. ${ }^{78}$ Corporations stand to lose substantial amounts of wealth if their corporate name is tarnished..$^{79}$ Particularly, they have a legitimate need to protect themselves from rivals which try to cause harm to their business by spreading false information. ${ }^{80}$ Damage can have far-reaching consequences, especially nowadays with the use of modern technologies. However, companies must be aware that by entering in

\footnotetext{
71 Emberland, op. cit. note 25, p. 106.

72 Stoll, M. L. Corporate rights to free speech?, Journal of Business Ethics, Vol. 58, Issue 1, 2005, p. 266.

73 Emberland, op. cit. note 25, p. 106.

$74 \quad$ Randall, op.cit. note 61, p. 71.

75 Ibid., p. 55.

76 Jackson, D. M., The Corporate Defamation Plaintiff in the Era of SLAPPs: Revisiting New York Times $v$. Sullivan, Wm. \& Mary Bill Rts. J., Vol. 9, 2000, p. 520.

77 Scolnicov A., Supersized Speech-McLibel Comes to Strasbourg, Cambridge LJ, Vol. 64, 2005 , p. 313. Similar Jackson, note 76,p. 492.

78 Jackson, op.cit. note 76, p. 522.

79 Ibid., p. 513

$80 \quad$ Scolnicov, op. cit. note 77 , p. 313.
} 
the business sphere, they voluntarily accept the risks of being subjects of public debate. $^{81}$

\subsubsection{Just satisfaction}

In case there was a violation of rights granted under ECHR or its protocols, the ECtHR can award just satisfaction to the injured party. The award is not an automatic consequence of a finding a violation of a right but is at the discretion of the Court. ${ }^{82}$ Just satisfaction may be afforded in respect of (a) pecuniary damage; (b) non-pecuniary damage and (c) costs and expenses. ${ }^{83}$ The redress can be provided as a declaratory judgment establishing violation(s) of the ECHR, or as a financial award consisting of pecuniary and/or non-pecuniary damages ${ }^{84}$ Pecuniary damage involves the decrease of the economic wealth of a person and can be calculated by relying on market prices, whereas non-pecuniary damage does not involve a diminution of the victim's patrimony and cannot be priced on the market. ${ }^{85}$ Although immaterial harm can never be "remedied" by money, most legal instruments(including the ECHR), foresee the possibility to award money to persons who suffered such harm. ${ }^{86}$ Moral damages are typically afforded for injuries such as harm to reputation, psychological harm, distress, frustration, humiliation and sense of injustice. ${ }^{87}$

Regarding companies, the problem has arisen when the Court granted them right to non-pecuniary damage, especially the right to monetary satisfaction. ${ }^{88}$ The first of such cases was Comingersoll S.A. v. Portugal. ${ }^{89}$ This case included in the scope of potential immaterial damages for the company „uncertainty in decision-planning, disruption in the management of the company and, albeit to a lesser degree, anxiety and inconvenience caused to the members of a legal entity's management

\footnotetext{
81 Jackson, op.cit. note 76, p. 514.

82 Rules of Court - Practice directions just satisfaction claims, 14 November 2016, Strasbourg, URL $=<$ http://www.echr.coe.int/Documents/Rules_Court_ENG.pdf>. Accessed 12 February 2017, p. 60, par. 1.

83 Rules of Court - Practice directions just satisfaction claims, p. 61, par. 6.

84 Nifosi-Sutton I., The Power of the European Court of Human Rights to Order Specific Non-Monetary Relief: a Critical Appraisal from a Right to Health Perspective, Harv. Hum. Rts. J., Vol. 23, 2010, p. 52. Altwicker-Hàmori, S., Altwicker, T., Peters, A., Measuring Violations of Human Rights An Empirical Analysis of Awards in Respect of Non-Pecuniary Damage under the European Convention on Human Rights, URL=< http://ssrn.com/abstract=2631404>. Accessed 12 February 2017, p. 13.

85 Altwicker-Hàmori, Altwicker, Peters, op.cit. note 84, p. 7.

86 Ibid., p. 8.

$87 \quad$ Nifosi-Sutton, op.cit. note 84, p. 54.

88 This was criticised on the grounds that a pecuniary loss is the only loss a company can suffer. Harding; Kohl, op.cit.note 14, p. 214.

89 Comingersoll S.A. v. Portugal (2001) 31 EHRR 31.
} 
team".$^{90}$ The controversy concerned the fact that the ECtHR identified immaterial damage of the directors with damages of the company itself. This caused dissension among members of the judicial team because it was incompatible with the principle of separate legal personality. Imputing the mental distress experienced by the management to the company the Court is in a sense piercing the corporate veil in reverse. ${ }^{91}$

\section{THE "VICTIM" STATUS UNDER ECHR (ARTICLE 34)}

Companies are given the right to file applications before the Court as "non-governmental organisations". However; the question is whether shareholders or other stakeholders (managers or employees) can file claims when the violation is directed against the company in which they have interests. ${ }^{92}$ The answer is relevant not only to the company, but also has consequences for its stakeholders, for a democratic society, and the rule of law. ${ }^{93}$ The problem arises because "victim" concept under ECHR is not clearly established but developed through court practice and is susceptible to constant evolution, which can cause increased level of legal uncertainty in the domain of human rights protection. ${ }^{94}$

Along-standing principle of company law is that company's rights and interests are separated from rights and interests of its shareholders and "corporate veil" can be pierced only under a limited number of circumstances. In the context of victim status, court has two options. The first is identification or lifting the corporate veil - rights of the company and the stakeholders are treated as being one and the same which means that state actions violate the human rights of the organisation

90 In one case Court spoke of "prolonged uncertainty in the conduct of its [company's] business and feelings of helplessness and frustration". See Centro Europa 7 S.R.L. and Di Stefano v. Italy (2012) GC, par. 221.

91 Wilcox, V., A Company's Right to Non-Pecuniary Damages An Enquiry into the Practices of the European Court of Human Rights and some of its High Contracting States, URL $=<$ https://ssc-rechtswissenschaften.univie.ac.at/fileadmin/user_upload/s_rechtswissenschaft/Doktoratsstudium_PhD/Expose1/Europarecht/A_Company_s_Right_to_Non-Pecuniary_Damages.pdf $>$. Accessed 7 February 2017, p. 3 .

92 The case law suggests that shareholders file these applications for several reasons: they misunderstand the meaning of „victimhood“, they believe that applications submitted by several company constituents enhance the chances of admissibility, they believe they represent identical interests as those of the company, they think that they have suffered a direct violation or because the company cannot itself take care of its own affairs, or doesn't want to initiate litigation. Emberland, M., The corporate veil in the case law of the European Court of Human Rights, Zeitschrift für ausländisches öffentliches Recht und Völkerrecht, Vol. 63, 2003, p. 946 fn 8.

93 Van Kempen, op.cit. note 3, p. 356.

94 Ćorić V., Model žrtve u svetlu novije jurisprudencije Evropskog suda za ljudska prava, Evropsko zakonodavstvo, Issue 49-50, 2014, p. 568. 
and the individual jointly. Under the second concept, the infringement against the company and the violation of the individual's rights are distinguished instead of being seen as one. ${ }^{95}$

The seminal case Agrotexim v. Greece ${ }^{96}$ has shown that ECtHR opted for the nonidentification principle as a starting point. ${ }^{97}$ Under the Court's jurisprudence, shareholders cannot in principle be identified with their company ${ }^{98}$ and are not regarded as "victims" unless the injury directly harms their property, or violates rights they enjoy (dividends, voting rights, or the right to a share in a company's assets after liquidation). ${ }^{99}$ However, the ECtHR established a few narrowly interpreted exceptions to this principle: a) impossibility for the company to apply to the court and b) case when the company is a mere vehicle for shareholders' business undertakings. ${ }^{100}$

The current practice of the ECtHR is criticised because the Court offered no guidelines for defining the standard that it will use to determine the victim status of future applicant shareholders, ${ }^{101}$ thus leaving them more vulnerable to government actions. ${ }^{102}$ It is pointed that the Court should abandon its current standard and adopt a more realistic multifactor test based on the following factors: whether the shareholder's right was infringed (as opposed to harm to its monetary interests), to what extent the shareholder exercised control over the company, to what extent it was impossible for the company itself to file suit, and the severity of the harm the shareholder suffered. ${ }^{103}$ What also remains unclear is the question whether broader interpretation (identification) should be applied only to the property rights, ${ }^{104}$ or should have a wider scope. ${ }^{105}$

\footnotetext{
95 Van Kempen, op.cit. note 3, p. 365.

96 Agrotexim and others v. Greece (1996) 21 EHRR 250.

97 Emberland, op. cit. note 92, pp. 950, 956.

98 Ibid., p. 949.

99 Tishler, S. C. A New Approach to Shareholder Standing before the European Court of Human Rights, Duke J. Comp. \& Int'l L., Vol. 25, 2014, p. 263-264.

100 The prevailing factors in this case shall be the degree of shareholding, holding of management positions and status as joint debtor for company loans. Other kinds of personal involvement may also suggest identification. Emberland, op. cit. note 92, p. 952-955.

101 Tishler, op.cit. note 99, p. 270.

102 Ibid., p. 279.

103 Ibid., p. 262-263 and 281-285.

104 Harding; Kohl, op.cit.note 14, p. 27.

105 Emberland, op. cit. note 92, p. 951.
} 


\section{CONCLUDING REMARKS}

The public is gradually becoming aware that companies can be harmed by illegal acts of other constituents in the society but there is no general agreement whether they can be full beneficiaries of human rights protection under international instruments. This is especially true for multinational corporations as opposed to small enterprises that would benefit from the protection.

Unlike other instruments, ECHR provides protection of companies' rights either explicitly or through ECtHR's interpretative powers. Court develops two-tiered scheme of protection of certain rights where standards relating to rights of companies are treated differently than that of individuals (e.g. wider margin of appreciation in applying restrictions on commercial speechor laxer standards in interpretation of companies' "home").

Apart from adopting the practice to take into consideration peculiarities of company's form when granting protection under the human rights charter, it can be advocated the possibility to create a separate charter of basic corporate rights that would take into consideration their specific nature, ${ }^{106}$ as it was applied in national laws (e.g. criminal liability).

\section{REFERENCES}

1. Aleksovski Đorđević S. Article 10 of the European convention in light of the jurisprudence of the European Court of Human Rights. FACTA UNIVERSITATIS-Law and Politics, Vol. 14, Issue 1, 2016, pp. 55-69.

2. Ćorić V., Model žrtve u svetlu novije jurisprudencije Evropskog suda za ljudska prava, Evropsko zakonodavstvo, Issue 49-50, 2014, pp. 567-577.

3. Dhooge, L. J., Human Rights for Transnational Corporations, J. Transnat'l L. \& Pol'y, Vol. 16, 2006, pp. 197-249.

4. Đurđević Z., Pravna osoba kao okrivljenik: temeljna prava i predstavljanje, Hrvatski ljetopis za kazneno pravo i praksu, Vol. 12, Issue 2, 2005, pp. 739-762.

5. Emberland, M., Protection Against Unwarranted Searches and Seizures of Corporate Premises under Article 8 of the European Convention on Human Rights: The Colas Est SA v. France Approach, Mich. J. Int'l L., Vol. 25, 2003, pp. 77-116.

6. Emberland, M., The corporate veil in the case law of the European Court of Human Rights, Zeitschrift für ausländisches öffentliches Recht und Völkerrecht, Vol. 63, 2003, pp. 945-969.

7. Grear, A., Redirecting human rights: Facing the challenge of corporate legal humanity. Hampshire, 2010.

8. Grear, A., Challenging corporate 'humanity': Legal disembodiment, embodiment and human rights. Human Rights Law Review, Vol. 7, Issue 3, 2007, pp. 511-543.

106 Harding; Kohl, op.cit.note 14, p. 52. 
9. Harding C.; Kohl U., Human rights in the market place: the exploitation of rights protection by economic actors, Routledge, 2016.

10. Helfer, L. R. The New Innovation Frontier-Intellectual Property and the European Court of Human Rights, Harv. Int'l LJ, Vol. 49, 2008, pp. 1-52.

11. Jackson, D. M., The Corporate Defamation Plaintiff in the Era of SLAPPs: Revisiting New York Times v. Sullivan, Wm. \& Mary Bill Rts. J., Vol. 9, 2000, pp. 491-523.

12. Ku, J. G., The Limits of Corporate Rights Under International Law, Chi. J. Int'l L., Vol. 12, 2011, pp. 729-754.

13. Nifosi-Sutton I., The Power of the European Court of Human Rights to Order Specific NonMonetary Relief: a Critical Appraisal from a Right to Health Perspective, Harv. Hum. Rts. J., Vol. 23, 2010, pp. 51-73.

14. Oliver, P., Companies and Their Fundamental Rights: A Comparative Perspective, International and Comparative Law Quarterly, Vol. 64, Issue 3, 2015, pp. 661-696.

15. Oliver, P., The protection of privacy in the economic sphere before the European Court of Justice, Common Market Law Review, Vol. 46, 2009, pp. 1443-1483.

16. Randall, M. H. Commercial Speech Under the European Convention on Human Rights: Subordinate or Equal?, Human Rights Law Review, Vol. 6, Issue 1, 2006, pp. 53-86.

17. Scolnicov A., Supersized Speech-McLibel Comes to Strasbourg, Cambridge LJ, Vol. 64, 2005, pp. 311-314.

18. Stoll, M. L. Corporate rights to free speech?, Journal of Business Ethics, Vol. 58, Issue 1, 2005, pp. 261-269.

19. Tishler, S. C. A New Approach to Shareholder Standing before the European Court of Human Rights, Duke J. Comp. \& Int'l L., Vol. 25, 2014, pp. 259-287.

20. Van den Muijsenbergh WH, Rezai S., Corporations and the European Convention on Human Rights, Pac. McGeorge Global Bus. \& Dev. LJ, Vol. 25, 2012, pp. 43-68.

21. Van Kempen, P. H., The Recognition of Legal Persons in International Human Rights Instruments: Protection Against and Through Criminal Justice?,Pieth, M.; Ivory, R. (eds.)Corporate Criminal Liability, Netherlands, 2011, pp. 355-389.

\section{ECHR}

1. European Convention for the Protection of Human Rights and Fundamental Freedoms, as amended by Protocols Nos. 11 and 14, 4 November 1950, ETS 5

2. Rules of Court, 14 November 2016, Strasbourg.

URL<http://www.echr.coe.int/Documents/Rules_Court_ENG.pdf>. Accessed 12 February 2017.

\section{Decisions:}

1. OAO Neftyanaya Kompaniya Yukos v. Russia (Just satisfaction) (2014) App. No. 14902/04.

2. Centro Europa 7 S.R.L. and Di Stefano v. Italy (2012) GC.

3. Société Colas Est and Others v. France (2004) 39 EHRR 17. 
4. Vinci Construction et GTM Génie Civil et Services c. France, App. No. 63629/10 et 60567/10.

5. Agrotexim and others v. Greece (1996) 21 EHRR 250.

6. Comingersoll S.A. v. Portugal(2001) 31 EHRR 31.

\section{WEBSITE REFERENCES}

1. Altwicker-Hàmori, S., Altwicker, T., Peters, A., Measuring Violations of Human Rights An Empirical Analysis of Awards in Respect of Non-Pecuniary Damage under the European Convention on Human Rights.

URL <http://ssrn.com/abstract=2631404>. Accessed 12 February 2017.

2. Isiksel T., The Rights of Man and the Rights of the Man-Made: Corporations and Human Rights. URL<https://ssrn.com/abstract=2546401 >.Accessed 13 April 2015.

3. Lafont, C., Should We Take the "Human" Out of Human Rights? Human Dignity in a Corporate World.

URL < https://ssrn.com/abstract=2768881>. Accessed 8 October 2016.

4. Macovei, M., Freedom of expression - A guide to the implementation of Article 10 of the European Convention on Human Rights, 2004.

URL<https://rm.coe.int/CoERMPublicCommonSearchServices/DisplayDCTMContent?do cumentId=090000168007ff48 >. Accessed 1 February 2017.

5. Sanchez-Graells, A., Marcos, F., 'Human Rights' Protection for Corporate Antitrust Defendants: Are We Not Going Overboard?, University of Leicester School of Law Research Paper No. 1404 , URL<https://ssrn.com/abstract=2389715>. Accessed 13 January 2017.

6. Scolnicov, A., Lifelike and lifeless in law: Do corporations have human rights?, University of Cambridge Faculty of Law Research Paper No. 13/2013.

URL <https://ssrn.com/abstract=2268537>. Accessed 30 September 2016.

7. Wilcox, V., A Company's Right to Non-Pecuniary Damages An Enquiry into the Practices of the European Court of Human Rights and some of its High Contracting States.

URL <https://ssc-rechtswissenschaften.univie.ac.at/fileadmin/user_upload/s_rechtswissenschaft/Doktoratsstudium_PhD/Expose1/Europarecht/A_Company_s_Right_to_Non-Pecuniary_Damages.pdf>. Accessed 7 February 2017. 